\title{
Aplikasi Kounseling dalam Pelaksanaan Kurikulum Pendidikan Islam
}

\author{
Nova Erlina
}

Dosen Fakultas Tarbiyah dan Keguruan, IAIN Raden Intan Lampung

Diterima: Oktober 2014. Disetujui: November 2014. Dipublikasikan: Desember 2014

\begin{abstract}
Abstrak: Secara umumnya kaunseling adalah proses untuk membantu seseorang mendapatkan celik akal (insegth) seterusnya dapat membuat pilihan atau membuat keputusan mengenai sesuatu masalah atau persoalan yang di hadapinya. Namun demikian, beberapa aspek kaunseling, serta ciri-ciri kaunselor yang berkesan dapat juga diaplikasikan dalam proses pengajaran dan pembelajaran. Sebagai kaedah dan teknik telah di gunakan dalam proses pengajaran dan pembelajaran selari dengan subjek yang di ajar. Penerapan kaunseling dalam proses pengajaran dan pembelajaran diharapkan dapat meningkatkan keberkesanan proses pengajaran dan pembelajaran. Tulisan ini membicarakan tentang kaunseling dari pada persipektif Islam serta aplikasi teknik kaunseling Islam yang boleh diterapkan semasa merangka dan melaksanakan kurikulum pendidikan Islam, yaitu dari pada aspek guru dan pelajaran
\end{abstract}

Kata Kunci: Aplikasi Konseling, Pendidikan Islam

\section{Pendahuluan}

Sejarah perkembangan bimbingan dan konseling Indonesia khususnya di sekolah secara resminya bermula dengan program bimbingan karir yang diperkenalkan dalam tahuntahun enam puluhan apabila konsep guru panduan karir mulai diperkenalkan dalam sistem persekolahan di Malaysia (Amla, Zuria dan Salleh, 2001). Kini layanan konseling telah mendapat tempat yang sewajarnya di Indonesia dan Malaysia. Pada masa ini bisalah dianggap konseling sebagai satu profesi yang menantang di Negara kita.

Kesungguhan kerajaan untuk menjadikan konseling sebagai satu profesi di Malaysia tercapai apabila kerajaan meluluskan undang-undang berkaitan dengan Akta Kaunselor 1998 (Undang-Undang Malaysia, 1998). Hasilnya hanya kaunselor-kaunselor yang terdaftar saja yang dibenarkan untuk menjalankan layanan kaunseling secara professional dan menggunakan nama jabatan sebagai kaunselor.

Namun demikian kemahiran-kemahiran asas kaunseling boleh diaplikasikan dalam sistem pendidikan dan digunakan oleh guru-guru biasa dalam membantu para peserta didik serta digunakan diwaktu proses belajar mengajar dalam kelas. Berhubungan dengan itu, penulisan ini mencoba untuk menerapkan aspek-aspek kaunseling dalam pembinaan kurikulum Islam dengan memberi fokus kepada aspek guru yang bertanggung jawab melaksanakan kurikulum dan juga aspek peserta didik yang menerima pendidikan yang di berikan oleh guru. Secara umumnya, tujuan utama pendekatan counseling diperkenalkan adalah untuk membantu peserta didik. Islam membuat tindakan yang seksama dalam mengahadapi perubahan, tantangan atau masalah. Ia juga boleh memberikan nasehat yang terus menerus kepada pelajaran-pelajaran dan pembentuk psikologi, mental, emosi dari dalam diri mereka.

Diera globalisasi ini, manusia semakin menghadapi berbagai bentuk tantangan yang bisa membawa kepada permasalahan didalam ummat Islam, khususnya dan generasi muda pada umumnya. kelahiran biadang kaunseling serta kaunselor diharapkan dapat membantu para pendidik menangani masalah remaja yang semakin menantang. Islam pada prinsipnya meminta setiap umat islam menjadi kaunselor dan para rasul dan utusan Allah adalah contoh teladan yang terbaik dan gigih memainkan peranan dalam bidang kaunseling. Dengan kata lain, konseling sebenarnya telah lama wujud didalam islam. Semuanya para rasul adalah bertujuan memberikan nasehat dan membawa kebenaran yang hakiki disisi Allah swt (Al-Quran: $2: 143,5: 87-88,16: 8)$. 
Dari perspektif islam, konseling adalah untuk ummat digalakkan dan kaedah umum konseling berasaskan kepada firman Allah SWT: "serulah kejalan tuhanmu (wahai Muhammad) dengan hikmah kebijaksanaan dan nasehat pengajaran yang baik" (Al-Quran 16:125).

\section{Metode Penelitian}

Mempertimbangkan kelangkaan penelitian tentang aplikasi konseling dalam pelaksanaan pendidikan islam, maka penelitian ini berusaha menjelaskan tentang apa dan bagaimana perlakuan konseling dalam kurikulum pendidikan islam. Tujuannya yaitu memberikan suatu wacana tambahan tentang konseling dalam kurikulum pendidikan islam. Penelitian ini menggunakan pendekatan kualitatif dengan menerapkan metode penelitian kepustakaan (library research). Penelitian berbasis literatur merupakan bentuk penelitian yang menggunakan literatur sebagai obyek kajian. Pendekatan ini sangat sesuai untuk kondisi Indonesia karena masih terbatasnya pemahaman kaunseling dalam kurikulum pendidikan islam. Data yang digunakan dalam penelitian ini berupa data sekunder, yaitu buku-buku, majalah-majalah dan dokumen-dokumen tertulis. Selain itu digunakan juga artikel-artikel yang diambil dari jurnal-jurnal kaunseling. Sedangkan untuk menjawab permasalahan, teknik analisis yang digunakan adalah teknik content analysis. Dalam teknik ini diperlukan data untuk menjawab setiap tahap penelitian, kemudian dilakukan content analysis terhadap data tersebut untuk menjawab atau mendeskripsikan pertanyaan penelitian pada tahap tersebut. Hasil content analysis ini kemudian digunakan sebagai bahan untuk menjawab pertanyaan penelitian pada tahap selanjutnya bersama dengan data lain yang diperoleh.

\section{Hasil dan Pembahasan}

Wan Hussain Azmi (1994) tmenguraikan metode kaunseling islam yang dapat dirumuskan seperti berikut: (1) Hikmah, terdapat 11 ciri utama dan bisa dikategorikan kepada: Hikmah yang berhubungan dengan sifat-sifat kaunselor, Mengamalkan sifat sifat kenabian (benar, amanah, menyampaikan dan kebijaksanaan), Keadilan, Meletakkan sesuatu pada tempatnya, Sabar, Berilmu pengetahuan dan berpengalaman luas, Ilmu pengetahuan yang sebaik -baiknya, Hikmah yang berhubungan dengan isi kandungan kaunseling, Berasaskan Alquran, Perkataan yang betul dengan hak dan kebenarank, Dalil yang tepat menerangkan kebenaran dan menghilangkan keraguaan, Hikmah yang berhubungan denagn alat dan strategi kaunseling, Alat yang mencegah kerusakan, Sesuatu yang digunakan sesuai dengan tempatnya. (2) Kata-kata nasehat yang baik nasehat yang bisa menjauhkan diri dari keburukan dengan cara memberi perangsang untuk meninggalkannya. kata-kata nasehat tersebut yang bisa diterima oleh hati serta masuk dengan mendalam kedalam perasan dengan lembut serta menjinakkan hatinya yang liar. (3) Perbincangan atau pembahasaan yang baik dengan tujuan menjauhkan diri dari perasaan dan Pegangan asas bagi islam adalah firman Allah yang bermaksud: "serulah kepada jalan tuhanmu dengan hikmah dan nasehat-nasehat yang baik, dan bertukar fikiranlah dengan mereka dengan cara yang lebih baik".

Kaunselor haruslah menggunakan teknik atau cara yang tepat dan berkesan apabila menjalankan aktivitas kaunseling dengan klaen sesuai dengan keadaan dan keperluan. M. Natsir (2002) menghuraikan hikmah sebagai ilmu yang shahih (benar dan sehat) yang menggerakkan kemauan untuk melakukan sesuatu perbuatan yang bermanfaat (berguna). Seterusnya beliu telah menjelaskan dalam firman Allah seperti berikut: "serulah kepada tuhanmu dengan hikmah, dengan cara bijaksana, dan tepat, sesuai dengan corak umat atau perorangan yang kamu hadapi, sesuai deengan keadaan ruang dan waktu" Surat An-nahl ayat 125 menggariskan panduan bagi mewujudkan hubungan fasilitator. Ayat berikut pula menjelaskan sifat dan akhlak rasulullah yang seharusnya menjadi panutan setiap ummat Islam khususnya mereka yang melibatkan diri denagn aktivitas kaunseling pada umumnya. "Adalah 
karena rahmat dari Allah maka kau (muhamad) bersikap lemah lembut kepada mereka. sekitarnya engkau berbudi kasar dan berhati bangis tentulah mereka menjauhkan diri dari lingkunganmu. Maka bermesyuaratlah dengan mereka dalalm segala urusan. Jika kemudian kau mengambil keputusan tawakallah kepad allah. Sesungguhnya allah mengecualikan orang yang bertawakal." Ali imran ayat: 159

Hadits Rasulullah yang diriwatkan oleh Abu amamah mengambarkan bagaiman baginda Rasulullah telah mencegah seorang pemuda yang sudah merancanakan untuk bezina. Para pemuda itu telah berjumpa dengan Rasulullah s.a.w. dan berkata "wahai Nabi Allah! apakah engkau memberi izinkepadaku untuk berzina?"' orang ramai yang hadir mendengar kata kata pemuda ini sangatlah marah tetapi Rasulullah s.a.w. meminta pemudaitu supaya menghampirinya. Apabila pemuda itu telah duduk dihadapannya, baginda rasullah bersabda, "Adakah engkau menyukai zina itu untuk ibu engkau?" pemuda itu menjawab, "Tidak. Dijadikan kiranya aku oleh Allah tebusan engkau." Nabi s.a.w. menyambung lagi, "begitu juga manusia, tiada menyukai zina itu untuk ibu mereka. Adakah engkau menyukainya untuk anak perempuan engkau?"

Pemuda tersebut memberi jawapan yang sama. Begitu juga halnya apabila baginda rasul bertanya tentang zina bagi saudara saudara perempuannya yang lain. Akhirnya dia menyedari tentang larangan yang keras terhadap perbuatan zina yang telah direncananya itu. Peristiwa tersebut telah menunjukan contoh tindakan secara 'Hikmah' didalam menyeru kepada kebaikan dan mencegah kemungkuran. didalam riwayat lain Rasulullah telah bersabda kepada Mu'az bin jabal yang akan berangkat menjadi Gabernur di Yaman. "Gembiralah, jangan timbulkan kebecian hingga orang lari” berikutnya diturunkan beberapa 'teknik' yang digunakan oleh Rasulullah didalam berdakwah yang sesuai dengan apa yang dianggap teknik atau kemahiran (ketrampilan)asas kaunseling: (1) Memilih dan menyusun kata yang tepat. Dalam kontek kaunseling ; keterampilan atau Kemahiran seperti penjelasakan, rumusan, refleksi dan interprestasi adalah berkaitan. (2) Diam atau hening apabila difikirkan percakapan tidak mendatangkan faedah. (3) M.Natsir (2002) menguraikanya sebagai mengadakan kontak pemikiran dan mencari titik pertemuan untuk maju secara sistematis. (4) Menjadi contoh amalan yang baik, maksud hadist "Barang siapa yang manyuruh kepada yang baik, maka hendaklah suruhannya itu sendiri dilakukan dengan cara yang baik. Mengikuti contoh atau 'modeling' memang juga digunakan sebagai salah satu kaedah kaunseling”

Selain daripada itu, mengamalkan teknik-teknik diatas beberapa amalan ibadat sunat direncanakan kepasa klaen setelah kaunselor memahami dan mengenal pasti masalah dan keperluan klaen. Misalnya didalam diri klien tidak dapat hendak membuat sesuatu keputusan dia bisa melakukan sembahyang sunah istikharah. Sekiranya dia sangat mengingikan sesuatu dia bisa menunaikan sembahyang hajat. Begitu juga dengan berzikir, membaca Al-Quran dan bertafakur.

Dalam usaha klien untuk mengharuskan amalan buruknya seperti berjudi, minum arak atau rokok dia boleh digalakkan syupaya berpuasa karena ibadat puasa atau memaksa dia menjauhkan diri dari jurang maksiat. Akhirnya seorang kaunselor islam boleh menyediakan doa doa supaya dapat menolong klien menguatkan imamnya dan juga membersihkan jiwanya. Pengalaman kaunseling haruslah memberi klien peluang membuat pendedahan dan penorakan kendari, mengenal pasti aspek aspek diri yang positif dan negatif, menilai, membuat pertimbangan, merancang, mencuba, menerima realiti diri dan hidup, serta membuat rancangan yang realistik dan objektif. Tidak ada set teknik yang tertentu yang boleh menjadikan peganangan yang muktamad didalam usaha untuk membri bimbingan yang berkesan kecuali merujuk kepada panduan yang digariskan dalam Al-Quran dan sunah Rasulullah s.a.w. 
Penghibatan individu sebagai kaunselor didalam aktiviti kaunseling haruslah dilihat didalam konteks tuntutan manusia terhadap sesama manusia sebagai kalifah Allah. Kemahiran kaunseling mengandungi hikmah yang sangat ditekankan didalam interaksi sesama manusia untuk menuju kejalan Allah. Seorang kaunselor islam haruslah memahami, menghayati serta mengamalkan asas asas islam yang terkandung didalam rukun islam. Keislaman harus merangkumi dan merentasi segala aspek kehidupannya segala usaha untuk memberi perkhidmatan yang brkesan harus difahami didalam konteks perannya sebagai kalifah allah untuk mendapat kerendahannya. Dia harus melaksanakan peraturan yang telah ditetapkan oleh allah didalam berbagai aspek kehidupan termasuk bidang kerjaya pilihannya. Dia tidak boleh 'mengislamkan' apa yang batil dan bertentangan dengan islam. Dasar itu telah digariskan dengan jelas sekali didalam Al-Quran dan sunah Rasulullah.

Pada asasnya seorang kaunselor yang berkesan adalah seorang manusia yang berkesan, yang peka kepada ciri ciri manusia yang berbagai ragam serta menyedari sifat sifat kemanusiaan sendiri, tabah, berani dan sedia menghadapi sebarang kemungkinan. Manusia bertanggung jawab terhadap diri sendiri dan kaunselor terutama sekali adalah menolong kliennya menolong dirinya sendiri-mengenal pasti tanggung jawab tersebut supaya dapat mengambil tindakan yan wajar. Insya'allah.

Pada asanya kaunseling adalah merupakan satu proses yang melibatkan hubungan dua hala iaitu kaunselor yang terlatih dengan individu yang memerlukan perkhidmatan atau lebih dikenali sebagai klien. Hubungan yangdimaksud adalah hubungan yang bertujuan untuk membantu klien. Bagi memastikan proses kaunseling dapan menjalankan dengan baik maka klein haruslah mempunyai kepercayaan atau kenyakinan terhadap kaunselor. Peterson dan Nisenholz (1991) menyatakan hubungan kaunseling adalah merupakan satu hubungan yang intim, klein akan menceritakan hal hal yang pribadi yang sangat sensitif yang tidak pernah diceritakan kepada orang lain.

Rogers (1951) pula menyatakan kaunselor perlu mempunyai sikap yang empati, ketulinan dan penerimaan tanpa syarat bagi membolehkan proses kaunseling berjalan lancar. Sehungan dengan itu adalah wajar setiap guru mempunyai sifat sifat dan ciri ciri kaunslor yang baik agar dapat menjalain hubungan yang baik akan dapat membantu melicinkan proses pengajaran dan pembelajaran.

Ini selaras dengan prinsip prinsip bimbingan dan kaunseling seperti yang dijelaskan oleh pihak kementrian pendidikan Malaysia (1993:5-3). Prinsip prinsip bimbingan untuk sekolah sekolah malaysia adalah seperti berikut:

1. Bimbingan dan kaunseling adalah proses pendidikan ang terancang dan berterusan.

2. Bimbingan dan kaunseling adalah untuk semua pelajar

3. Semua pelajar mempnyai hak untuk mendapatkan pertolongan apabila mereka memerlukannya.

4. Bimbangan dan kaunseling adalah untuk melayan keprluan pelajar bagi perkembangan potensi dan kebolehan mereka.

5. Bimbingan dan kaunseling adalah untuk menolong pelajar memahami dirinya dan orang lain dengan mendalam, menjelajah tujuan tujuan hidupnya dan menolong memilih serta merancang hidupnya dengan berkesan.

6. Bimbingan dan kaunseling berorentasi masa sekarang dan masa depan

7. Bimbingan dan kaunseling menolong individu menyadari kelemahanya dan memberi fokus kepada kekuatannya.

8. Bimbingan dan kaunseling adalah tanggung jawab bersama.

9. Bimbingan dan kaunseling memerlukan pemahaman yang mendalam dan menyeluruh mengenai pelajar.

10. Setiap individu berbeza dalam gaya, ketangkasan dan mendorong untuk belajar 
11. Pembentukan individu dipenangaruhi oleh keseluruhan pengalaman dalam alam persekitarnya

12. Bimbingan dan kaunseling adalah untuk pengetahuan dan kesepaduan psikofizikal.

13. Bimbingan dan kaunseling hendaknya dijalankan berdasarkan etika kaunseling.

Mizan (1992) juga menyatakan perkhidmatan yang berorientasikan perkembangan adalah bertujuan memberi erti pendidikan yang sebentar kepada pelajar. Perkhidmatan yang diberikan adalah untuk memenuhi nkeperluan keperluan yang diberlakukan oleh pelajar srat mestialh selaras dengan falsafah dan objektif sekolah yang merancangkannya. Sehubungan denagn itu dalam merangka kurikulum pendidikan islam, guru yang akan mengajar harus menyedari bahawa mereka juga berperanan membantu pelajar dalam pelbagai aspek kehidupan pelajar disekolah. pendekatan yang sesuai dengan perubahan masa dan zaman perlu diketahui oleh mereka. antara prinsip prinsip yang perlu dipatuhi adalah seperti berikut.

Memberi bantuan kepada semua pelajar guru harus memberi bantuan kepada semua pelajar sekolah dengan sebaik mungkin. Ini bermakna bantuan bukan hanya kepada pelajar yang berada dibawah tanggungannya secra langsung seperti sebagai guru tingkatan atau guru penasihat. Bantuan dan bimbingan bukan hanya diberi kepada pelajar yang lemah semata mata

Niat yang iklas dan kesediaan untuk membantu Keikhlasan memang sesuatu yang sangat penting dalam melakukan sesuatu perkara. Selain dari pada itu, guru juga harus bersedia untuk membantu pelajar. Sekiranya guru hanya berniat untuk mengajar tanpa mengambil kira sikap an tingkah laku pelajar didalam kelasanya maka proses pengajaran dan pembelajaran berjalan dengan lancar.

Tidak menilai atau melabel pelajar serta menerima tanpa syarat. Guru tidak seharusnya mempunyai prasngka atau tanggapan negatif terhadap para pelajarnya. Kepercayaan atau tanggapan negatif terhadap seseorang itu dipanggil sebagai melabel. Sekiranya guru sudah melabel pelajar maka sukurlah guru itu hendak membantu pelajar yang dilabelnya itu. Sebagai contohnya seseorang guru menyatakan pelajar pelajar dikelas hujung itu pemalas dan tidak mahu belajar, make seetiap kali masuk guru tidak akan mengajar dengan bersungguh sungguh karana guru merasakan bahawa pelajar kelas tersebut memang tidak mahu belajar.

Sebagai seorang guru yang berdedikasi, guru seharusnya mempunyai sikap yang terbuka dan pisitif terhadap semua pelajarnya. walaupun pelajar itu telah dilabel sebagai pemalas atas seorang yang degil dalam kelasnya uru harus memberi peluang kepada pelajar untuk berubah. Guru juga tidak meletakkan sebarang syarat untuk membantu pelajar terutamanya semasa proses pengajaran dan pembelajaran.

Membantu kelemahan peelajar dan membantu mempertingkat potensi pelajar. Proses pengajaran dan pembelajaran akan hanya dianggap sebagai berjaya jika pelajar memahami apa yang disampaikan oleh guru. Namun demikian ada juga guru menghabiskan sukatan yang telah ditetapkan bagi sesuatu yang tempoh masa biasanya setahun. Namun demikian ada juga ketikanya pelajar, terutamanya dikelas hujung akan menghadapi masalah untuk mengikuti sukatan pelajar yang disampaikan. Disinilah peranan guru untuk membantu pelajar yang lemah dan tidak hanya mengajar mengikut sukatan yang telah ditetapkan. Guru boleh menngikut belajar mengikut sukatan tetapi bagaimanakah guru dapat memastikan yang pelajar memahami apa yang disampaikan.

Guru juga berperan untuk meningkatkan potensi diri pada pelajarnya. Ini dapat dilakukan denagn mendekati pelajar sambil memberikan sokongan kepada pelajar terutamanya dalam segi sokongan moral. Memahami dan menghormati budaya pelbagai pelajar. Sebagai sebuah negara majmuk, guru tidak boleh lari dari pada menerima pelajar dari pada pelbagai 
keturunan, agama dan juga budaya. Proses pengajaran juga harus dijalankan secra adil dan seksama tanpa menilai latar belakang etnik sesuatu kaum.

Pertamakali dalam merangka sebuah kurikulum, pelanggan atau penerima kurikulum itu harus juga diberi perhatian. Penggubal dasar seharusnya menyedari bahawa setiap pelajar itu berbeza dalam pelbagai aspek. Setiap manusia mempunyai keistimewahan yang tersendiri dan berbeza dalam pelbagai aspek antara satu sama lain. Oleh itu guru haruslah memberi sedikit tumpuan kepada perbezaan individu tersebut.

Dalam proses pengajaran dan pembelajaran, guru harus menggunakan pelbagai pendekatan dalam kelasnya agar dapa diterima oleh semua pelajarnya. Sebagi contohnya mungkin ada pelajar yang dapat memahami isi pelajaran denagn sekali penerangan yang berulang kali untuk memahami sesuatu isi pengajaran.

Begitu juga ada pelajar yang cemerlang dari segi akademik tetapi tidak mahir dalam kerja tanagn seperti ang berbentuk teknikal. Ada pelajar yang mudah memahami subjek subjek yang dianggap sukar seperti metematik dan sains tetapi tidak pandai dalam mata pelajaran lukisan. oleh itu, guru harus memberi sedikit tumpuan kepada kebolehan dan keupayaan setiap individu. Denagn cara ini, guru dapa membantu pelajar mengenali potensi dari masing masing.

Biasanya rami berpendapat perkhidmatan bimbingan dan kaunseling hanya diberi kepada individuyang bermasalh sahaja. Namun hakikatnya perbezaan individu yang telah dinyatakan tadi membolehkan perkhidmatan diberikan kepada semua pelajar. Amla (1995) menyarankan untuk memudahkan perkhidmatan kaunseling dimana pelajar pelajar menjadi kumpulan sasaran perkhidmatan ini, mereka boleh dikategorikan kedalam empt kategori besar berasaskan kepada tahap pengetahuan diri dan berjaya dismping sikap terhadap masa depan mereka. walaupun pada asanya pembahagian atau pengkategorian ini khusus untuk perkhidmatan kaunseling, penulis berpendapat ia juga boleh diterapkan semasa merangka kurikulum dari segi kepentingan pelajar.

Kumpulan kumpulan tersebut adalah kumpulan yang mempunyai daya inisiatif, kumpulan pencari maklumat, kumoulan yang keliru dan kumpulan tercicir. Kumpulan yang mempunyai daya inisiatif adalah terdiri dari pada pelajar yang mempunyai hala tuju dan tentang diri, mempunyai nilai diri secara realistik berhubung denagn sistem sosial dan pilihan kerjaya. Kumpulan peencari maklumat adalah terdiri dari pada mereka yang mempunyai sedikit pengetahun tentang diri mereka dan tau minat sendiru tetapi tidak berapa yakin.

Kumpulan yang seterusnya ialah kumulan nyang keliru. Pelajar dalam kumpulan ini kelihatan keliru dalam banyak kehidupan mereka. mereka tidak dapat melakukan sesuatu perkara sehingga selesai sebaliknya senantiasa ertukar tukar aktiviti. Kumpulan terakhir ialah kumpulan tercicir yang dapat disifatkan sebagai telah hilang minat dalam aktiviti aktivi yang biasa dilakukan oleh kebanyakan pelajar didalam kumpulannya berkaitan dengan diri dan masyarakat. Mereka lebih cenderum melakukan aktiviti yang merosakkan diri an masyarakat. Jika dalam proses kaunseling, mereka yang berada dalam kumpulan ini memerlukan rawatan yang serius.

Berdasarkan kepada empat kumpulan utama yang telah dinyatakan, penulis percaya tidak ada gunanya jika sesebuah kurikulum itu diberikan kepada semua pelajar tidak ada gunanya jika sesebuah kurikulum itu diberikan kepada semua pelajar tanpa mengambil kira latar belakang keupayaan mereka. sebagai contohnya ada pelajar ditingkatan empat masih tidak mampu membaca dan menulis dengan baik. Namun oleh kerena guru terpaksa mengikuti kurikulum yang telah disediakan maka guru terpaksa menghabiskan sukatan tanpa mengambil kira keupayaan pelajar. Akibatnya pelajar akan merasa terabai dan seterusnya hilang minat untuk belajar.

\section{Simpulan dan Saran}


Walaupun bimbingan dan kaunseling lebih berfokus kepada aspek perkembangan diri indivodu, beberapa aspek perkembangan itu boleh juga diaplikasikan dalam pembinaan sesebuah kurikulum, Penulis telah membincangkan dua aspek yang boleh diberi penekanan dalam merangka kurikulum pendidikan islam iaitu aspek yang berkaita dengan guru sebagai invidu yang mengajar dan aspek pelajar yang menerima pembelajaran daripada guru. kedua dua aspek ini dirasakan sanga penting kerana proes pengajaran yang berkesan seharusnya bermula daripada hubungan sesama insan yang baik iaitu hubungan antara guru dan pelajar. Kurikulum yang disediakan nanti seharusnya dapat memenuhi kehendak subjek tau kandungan mata pelajaran itu sendiri serta keupayaan pelajar yang akan mengikutinya.

\section{Daftar Pustaka}

Al-Quran dan terjemahanya, yayasan penyelengara penterjemah/pentafsiran Al-Quran, jakarta, 1971.

Amla Mohd. Salleh.1995. kaunseling dan sekolah. prosiding seminar kaunseling dalam pendidikan : 9-23.

Amla Mohd. Salleh zuria mahmud \& salleh Amat.1999. pengantar bimbingan dan rundingcara. Modul PJJ. Bangi: pJJ, UKM.

Peterson, j. Vincent \& nisenholz. Benard. 1991 orientation to kaunselin. Bosten : Allyn and bacon.

Rogers,C.R.1951. client-centered therapy. Boston : houghton Miffifin.

Kementrian pendidikan malaysia.1993. panduan pelaksanaan perkhimatan bimbingan dan kaunseling disekolah menengah. Kuala lumpur: unit bimbingan dan kaunseling, bahagian sekolah, kementrian pendidikan malaysia.

Mizan Adiliah Ahmad Ibrahim (pnyt.).1992. perkhidmatan bimbingan dan kaunseling disekolah. Kula lumpur : dewan bahasa dan pustaka.

M.Natsir, Fiqhud dakwah, pustaka nasional pte Ltd., 1982.

Undang undang malaysia. 1998. Akta kaunselor 1998 (akta 580). Kuala lumpur: PNMB.

Wan Husain Azmi Abdul Kadir. 1994. Kaunseling dan psikologi menurut islam. Kuala lumpur: DBP 
